\title{
Extensive heterogeneity of the protein composition of Chlamydia trachomatis following serial passage in two different cell lines
}

\author{
Prabhat C. Goswami, ${ }^{1}$ Evangelia Vretou ${ }^{2}$ and Subir K. Bose ${ }^{1 *}$ \\ ${ }^{1}$ Department of Microbiology, St Louis University School of Medicine, St Louis, MO 63104-1028, USA \\ ${ }^{2}$ Institut Pasteur Hellenique, 11521 Athens, Greece
}

(Received 30 November 1989; revised 6 April 1990; accepted 24 April 1990)

\begin{abstract}
To determine if the host-modulated adherence characteristics of the intracellular bacterial pathogen Chlamydia trachomatis were due to the acquisition of altered surface-exposed proteins, highly purified chlamydiae grown in two different host cells were analysed. Two serovars, $L 1$ and $\mathrm{E}$, were grown for multiple passages in both HeLa and McCoy host cells. Numerous protein differences in the chlamydial elementary bodies (EB) of each serovar grown in the two different hosts were detected by two-dimensional (2-D) gel electrophoresis and fluorography of radioactively labelled proteins. At least four to six serial passages in the alternative host were necessary before the changes were apparent. Iodination of suspensions of purified chlamydiae and 2-D electrophoresis revealed several surface proteins that were determined by the host cells in which the bacteria had replicated. These iodinated chlamydial proteins were removed by treatment of the iodinated EB with trypsin, indicating their location at the bacterial surface. Two of the major constituents of the outer-membrane complex, the cysteine- and methionine-rich $60 \mathrm{kDa}$ and $40 \mathrm{kDa}$ proteins, remained unchanged in both molecular mass and charge during the host adaptation. Several chlamydial proteins capable of binding iodinated host membrane preparations also exhibited hostdependent alterations. Immunoblotting experiments with a rabbit and a human polyclonal sera indicated that distinct host-specified chlamydial proteins were reactive with the two sera.
\end{abstract}

\section{Introduction}

The identity of ligands mediating the attachment to host cells of Chlamydia trachomatis, an obligatory parasitic bacterial pathogen, is not established. Using several lectins as probes to identify the chlamydial ligands responsible for the initial adherence of the elementary bodies (EB) to host cell membrane, we reported that treatment of the host cells with wheat germ agglutinin resulted in a lectin-dose-dependent enhancement of adherence (Bose et al., 1983). In a recent study we noted that the adherence of HeLa- but not McCoy-grown $C$. trachomatis was specifically stimulated when the host cells had been pretreated with the lectin (Bose \& Goswami, 1986). In addition, affinity chromatography of ${ }^{32} \mathrm{P}$-labelled, highly purified EB on agarose-bound WGA showed that the purified EB of HeLa-grown $C$. trachomatis serovar LGV440 (L1) bound to the lectin gel and could be eluted with buffer containing $N$-acetylglucosamine. After multiple passages of serovar Ll and

Abbreviations: 2-D, two-dimensional; EB, elementary bodies; (M)OMP, (major) outer-membrane protein; TBS, Tris-buffered saline. another genital serovar, UW31(K), in the alternative host cell McCoy, a mouse fibroblastic cell line, the chlamydiae neither bound to the lectin columns nor showed the lectin-induced enhancement of adherence to the host cells (Bose \& Goswami, 1986). Infectivity assays confirmed the affinity chromatography and the adherence data.

During adaptation of yolk-sac-grown isolates of trachoma serovars in McCoy cell cultures, no change was detected in the antigenic properties of the chlamydiae (Gordon et al., 1971). Acquisition of stable infectivity properties by a single passage of egg-grown Chlamydia psittaci GPIC in McCoy cell cultures was first noted by Allan \& Pearce $(1979 a)$. After a single passage in cell culture, the progeny acquired enhanced ability to infect McCoy cells without centrifugal deposition of the bacteria onto the monolayer cultures. In addition, neutralization studies revealed that yolk-sac-grown GPIC had an egg-derived antigen that played a role in the unassisted infection of McCoy cells (Allan \& Pearce, $1979 b$ ). Changes in the sedimentation behaviour of the EB of $C$. psittaci $6 \mathrm{BC}$ after passage in cell culture (Kordova et al., 1977; Neuman et al., 1980), and in the 
lysosomal stability of $C$. psittaci $6 \mathrm{BC}$-infected mouse macrophages (Kordova et al., 1972a) and L cells (Kordova et al., 1972b), have been documented.

We have analysed the protein profiles of highly purified EB of C. trachomatis grown in two different host cells, $\mathrm{HeLa}$ and McCoy. Distinct alterations in $\left[{ }^{35} \mathrm{~S}\right]$ cysteine $/\left[{ }^{35}\right.$ S $]$ methionine-labelled proteins and in ${ }^{125} \mathrm{I}-$ labelled surface proteins of two serovars, L1 and E, occurred during the growth of $C$. trachomatis in the different cell lines. Chlamydial proteins to which isolated host cell membranes could bind, and the immune reactive proteins were also altered by adaptation in the different host cells.

Some of the data reported here were first presented by Goswami et al. (1988) and Vretou et al. (1989a).

\section{Methods}

Chlamydial growth and purification. C. trachomatis serovars LGV440 (L1) and $\mathrm{E}$ were grown in monolayer cultures of mycoplasma-free $\mathrm{HeLa}$ 229 and McCoy cells (Bose \& Goswami, 1986). Infected cells were detached with sterile glass beads, disrupted by sonication, and the EB purified free of contaminating host material and chlamydial reticulate bodies (Vretou et al, 1989 b). Mixing experiments had shown that less than $0.02 \%$ of host-derived radioactively labelled, hot trichloroacetic acid-precipitable protein co-purified with the EB of C. trachomatis (Vretou et al., 1989b), and electron microscopy of the final preparations did not reveal any reticulate bodies, the non-infectious, developmental form of chlamydiae. Detection of mycoplasma was done using an antiDNA monoclonal antibody from a hybridoma isolated in the laboratory by E.V.

Metabolic labelling of chlamydiae with $\left[{ }^{35}\right.$ S $]$ methionine plus $\left[{ }^{35}\right.$ S $]$ cysteine (Trans S). Confluent cultures of HeLa or McCoy cells were infected with chlamydiae, and either 8 or $18 \mathrm{~h}$ post-infection with $\mathrm{Ll}$ or $\mathrm{E}$, respectively, the medium was replaced with labelling medium that contained $5 \%$ of the normal amount of methionine, and emetine, an irreversible inhibitor of eukaryotic protein synthesis, at $1 \mu \mathrm{g} \mathrm{ml}^{-1}$. After $1 \mathrm{~h}$ at $37^{\circ} \mathrm{C}, 500 \mu \mathrm{Ci}\left[{ }^{35} \mathrm{~S}\right] \mathrm{T}$ rans $\mathrm{S}$ (E. coli hydrolysate containing $70 \% \mathrm{~L}-$ methionine and $15 \%$ L-cysteine, $1103 \mathrm{Ci} \mathrm{mmol}^{-1}, 40 \cdot 8 \mathrm{TBq} \mathrm{mmol}^{-1}$; ICN Radiochemicals) was added to each $175 \mathrm{~cm}^{2}$ flask, and the labelled EB were isolated as usual. Aliquots were stored at $-80^{\circ} \mathrm{C}$.

${ }^{125}$ I-labelling of chlamydial EB . Surface-labelling was accomplished with 1,3,4,6-tetrachloro-3 $\alpha, 6 \alpha$-diphenylglycouril (Iodogen; Pierce). Freshly purified EB was sedimented by centrifugation, the pellet resuspended in HEPES/sucrose/cation buffer (10 mM-HEPES, pH 7-3, $1 \mathrm{~mm}-\mathrm{MgCl}_{2}, 1.5 \mathrm{~mm}-\mathrm{CaCl}_{2}, 90 \mathrm{~mm}-\mathrm{NaCl}$ and $0.2 \mathrm{M}$-sucrose) and transferred to a microfuge tube coated with Iodogen according to the instructions of the supplier. Carrier-free $\mathrm{Na}^{125} \mathrm{I}(100 \mu \mathrm{Ci}$ in $10 \mu \mathrm{l}$; ICN Radiochemicals) was added, and held in ice for $10 \mathrm{~min}$. Unreacted isotope was removed by gel filtration of the EB suspension through a column of G-25 Sephadex, equilibrated with phosphate-buffered saline $(0.14 \mathrm{M}$-sodium chloride, $0.01 \mathrm{M}$-sodium phosphate, $\mathrm{pH} 7.2)$ containing $0.5 \%(\mathrm{w} / \mathrm{v})$ bovine serum albumin and $0.05 \% \mathrm{NaN}_{3}$. Fractions containing the EB were pooled, the chlamydiae concentrated by centrifugation, and aliquots stored at $-80^{\circ} \mathrm{C}$. No differences in the polypeptide pattern could be detected between freshly labelled and frozen-thawed samples.

Two-dimensional (2-D) electrophoresis. Isoelectric focusing in the first dimension followed by SDS-PAGE in the second dimension was essentially according to O'Farrell (1975). Samples of radioactively labelled EB retrieved from $-80^{\circ} \mathrm{C}$ were sedimented by centrifugation and the pellet solubilized (Ames \& Nikaido, 1976; Batteiger et al., 1985). After dilution with 2 vols of sample dilution buffer [ $9 \cdot 5 \mathrm{M}$-urea, $5 \%$ (v/v) $\beta$-mercaptoethanol, $1.6 \%$ (v/v) Servalyt ampholytes, $\mathrm{pH} 3$ to $10,0.4 \%(\mathrm{v} / \mathrm{v})$ Servalyt, $\mathrm{pH} 3$ to 7 , and $8 \%(\mathrm{v} / \mathrm{v}) \mathrm{NP}-40$ ], the solubilized proteins were loaded on the basic end of the cylindrical focusing gels containing the ampholytes. The electrofocusing was for $16 \mathrm{~h}$ at $350 \mathrm{~V}$ followed by $\mathrm{l} h$ at $500 \mathrm{~V}(6100 \mathrm{~V} \mathrm{~h})$. For electrophoresis in the second dimension, the cylindrical gels were equilibrated for $15 \mathrm{~min}$ in sample buffer (Laemmli, 1970), and secured to the top of a $3 \%(w / v)$ polyacrylamide stacking gel. The resolving gel was a $7-20 \%$ SDSpolyacrylamide gradient gel. Molecular mass markers were from BioRad. The labelled proteins were detected either by fluorography or autoradiography, depending upon the isotope.

Immunoblotting for the detection of chlamydial proteins. Chlamydial proteins, resolved by either 1- or 2-D-electrophoresis, were transferred (Towbin et al., 1979) to Immobilon P membrane sheets (Millipore) in a Bio-Rad Trans-Blot apparatus at $100 \mathrm{~mA}$ constant current for $16 \mathrm{~h}$ at $4{ }^{\circ} \mathrm{C}$. Transferred proteins were visualized with Poinceau S, destained, and then blocked for $2 \mathrm{~h}$ at $37{ }^{\circ} \mathrm{C}$ with $5 \%$ non-fat milk in Tris-buffered saline (TBS, $50 \mathrm{~mm}$-Tris/ $\mathrm{HCl}, \mathrm{pH} 7 \cdot 4,0.9 \% \mathrm{NaCl}$ ) containing $0.05 \%$ sodium azide. The blots were incubated with appropriately diluted anti-major outer-membrane protein (MOMP) monoclonal antibody (KB-8), or anti-chlamydial-60 kDa monoclonal antibody (Virostat) or with other sera to detect the immunoreactive chlamydial proteins. After washing the blots three times with TBS containing $0.025 \%$ Tween-20, the antibodies bound to the chlamydial proteins were visualized with horseradish peroxidase-conjugated goat anti-human IgG (Dakopatts), anti-mouse (Zymed) or donkey anti-rabbit IgG, (Amersham) and 4-chloro-1-naphthol (Sigma) according to the manufacturers' instructions.

Detection of host cell membrane-binding proteins. Membrane-containing fractions were obtained by two published procedures. Monolayer cultures of HeLa cells were extracted with the non-ionic detergent octyl- $\beta$-D-glucopyranoside (Marriott et al., 1987) and the extract was iodinated using Iodobeads (Pierce). The second method used to prepare HeLa membrane was that of Wenman \& Meuser (1986). Purified EB of various serovars grown in the different host cells were subjected to 1-D SDS-PAGE, and the chlamydial proteins transferred to Immobilon $P$ membrane sheets (Towbin et al., 1979). After blocking with TBS containing $5 \%(\mathrm{w} / \mathrm{v})$ non-fat milk, the immobilized chlamydial proteins were incubated at $22^{\circ} \mathrm{C}$ for $18 \mathrm{~h}$ with the iodinated HeLa membrane fraction. Host cell membrane material bound to the chlamydial proteins was visualized by autoradiography. Identical results were obtained with the membranes prepared by the two different procedures.

\section{Results}

\section{2-D analysis of the host-specified ${ }^{35} S$-labelled proteins of C. trachomatis}

C. trachomatis serovars $\mathrm{L} 1$ and $\mathrm{E}$ were grown in the two different hosts, HeLa and McCoy, for at least 20 serial passages. Chlamydiae were metabolically labelled during intracellular growth in the host cells with a mixture of $\left[{ }^{35} \mathrm{~S}\right]$-cysteine and $\left[{ }^{35} \mathrm{~S}\right]$ methionine (Trans S) in the presence of emetine. The labelled proteins in the purified EB were analysed by 2-D gel electrophoresis and 
fluorography. The protein patterns of serovar $\mathrm{E}$ grown in $\mathrm{HeLa}$ and in McCoy cells (E/Hela and E/McCoy, respectively) are shown in Figs $1(a)$ and $(b)$. The unique, host-specified ${ }^{35} \mathrm{~S}$-labelled proteins detected in these and similar gels, including those surface-labelled with ${ }^{125} \mathrm{I}$, are summarized in Table 1. As reported previously (Batteiger et al., 1985) most of the chlamydial proteins are either acidic or neutral. Approximately 120 to 150

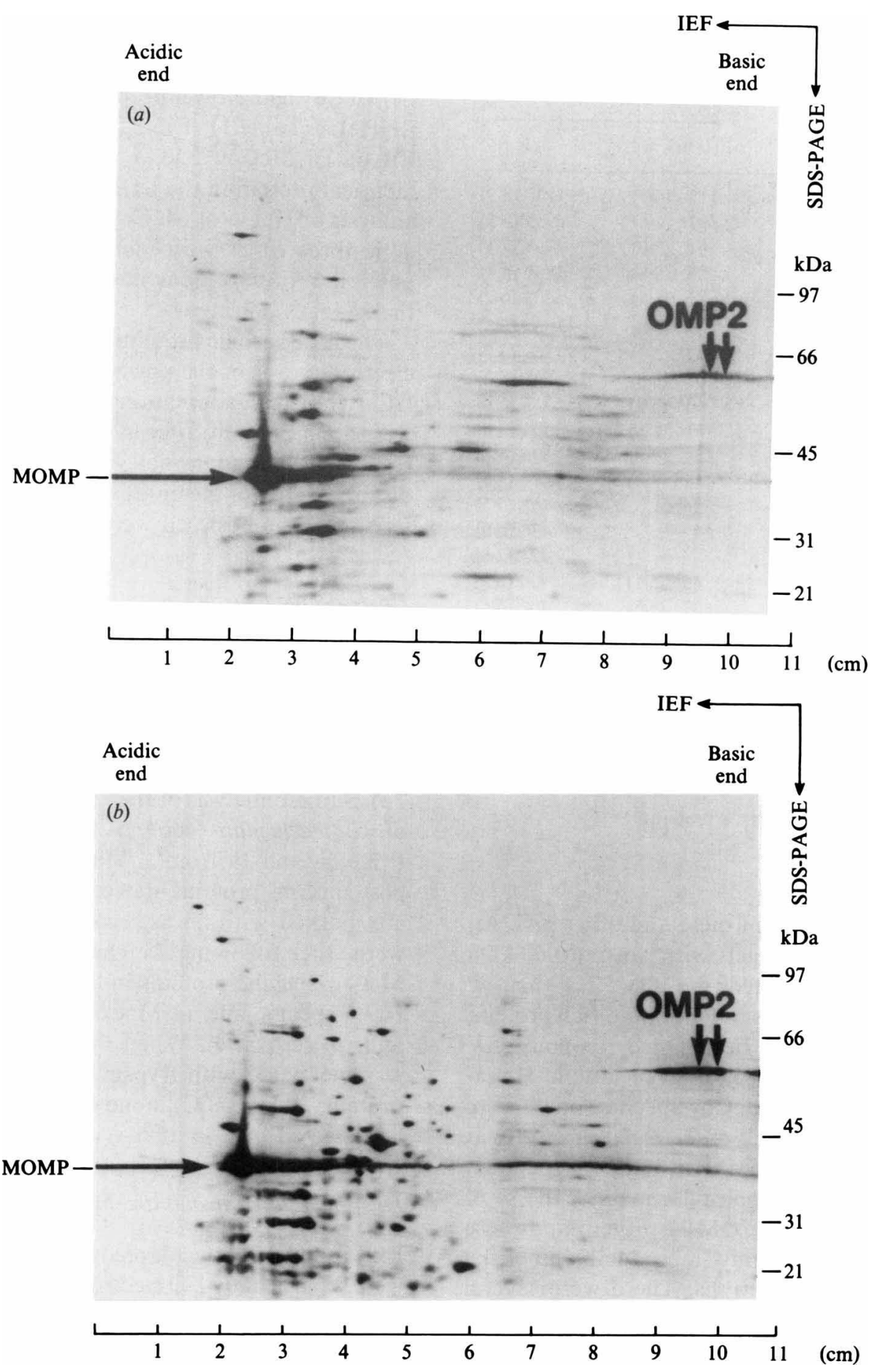

Fig. 1. Protein profiles of $C$. trachomatis serovar E, grown for $>15$ passages in $(a)$ HeLa or $(b)$ McCoy cells. The EB were labelled with ${ }^{35} \mathrm{~S}$-Trans $\mathrm{S}$ in the presence of emetine during intracellular growth, purified, and subjected to analysis by 2-D electrophoresis and fluorography as described in Methods. The positions of the MOMP and the $60 \mathrm{kDa}$ OMP2 are indicated. The positions of molecular mass markers $(\mathrm{kDa})$ are also shown. 
Table 1. Unique host-specified proteins of ${ }^{35} S$-labelled serovars L1 and E grown in HeLa or McCoy cells

The data are summarized from the fluorographs shown in Fig. 1, fluorographs of 2-D gels of serovar L1, and autoradiographs of ${ }^{125}$ I-labelled surface proteins of the two serovars. Numbers in parentheses represent distance in $\mathrm{cm}$ from the basic end of the gel.

\begin{tabular}{|c|c|c|c|}
\hline \multicolumn{2}{|c|}{$\begin{array}{l}\text { HeLa-specified proteins } \\
\text { (kDa) }\end{array}$} & \multicolumn{2}{|c|}{$\begin{array}{l}\text { McCoy-specified proteins } \\
(\mathrm{kDa})\end{array}$} \\
\hline L1 & $\mathbf{E}$ & L1 & $\mathbf{E}$ \\
\hline $110^{*}(7 \cdot 8)$ & $100(8 \cdot 6)$ & $112(6.9)$ & $112 \quad(8.9)$ \\
\hline $98 \quad(7 \cdot 8)$ & $98^{*}(7 \cdot 1)$ & $97^{*}(7 \cdot 6)$ & $98^{*}(8 \cdot 5)$ \\
\hline $95 \quad(7 \cdot 3)$ & & $91 \quad(3.0)$ & $96 *(7 \cdot 1)$ \\
\hline $90 \quad(6 \cdot 0)$ & $76^{*}(8 \cdot 2)$ & $86 \quad(9.8)$ & $83^{*}(6 \cdot 4)$ \\
\hline $83^{*}(5 \cdot 4)$ & & $81 \quad(8 \cdot 2)$ & $75^{*}(6 \cdot 0)$ \\
\hline $77 \quad(5 \cdot 1)$ & & $74 \quad(8 \cdot 6)$ & $65 \quad(6 \cdot 3)$ \\
\hline $76(4 \cdot 1)$ & $60 \quad(6 \cdot 8)$ & $73 *(5 \cdot 5)$ & $56 \quad(6 \cdot 5)$ \\
\hline $75 \quad(3.8)$ & $56 \quad(4 \cdot 1)$ & $65^{*}(6 \cdot 0)$ & $54^{*}(5 \cdot 2)$ \\
\hline $75 \quad(5 \cdot 9)$ & $55^{*}(7 \cdot 7)$ & $63^{*}(3.9)$ & $51^{*}(6 \cdot 8)$ \\
\hline $75 \quad(7 \cdot 3)$ & $46^{*}(6 \cdot 0)$ & $61 \quad(6 \cdot 6)$ & $50 \quad(5 \cdot 6)$ \\
\hline $70^{*}(6.8)$ & & $54 \quad(2 \cdot 6)$ & $49 \quad(6 \cdot 7)$ \\
\hline $67^{*}(4 \cdot 1)$ & & $46 \quad(3.9)$ & $47 \quad(3.5)$ \\
\hline $63 \quad(5 \cdot 8)$ & & & $46^{*}(5 \cdot 7)$ \\
\hline $56^{*}(6.0)$ & & & $43 \quad(6.0)$ \\
\hline & $36 \quad(7 \cdot 3)$ & & $42 \quad(2 \cdot 6)$ \\
\hline $45 \quad(4 \cdot 6)$ & $34 \quad(6 \cdot 8)$ & $45 \quad(5 \cdot 1)$ & $40 \quad(6 \cdot 3)$ \\
\hline $43 \quad(6 \cdot 0)$ & $32^{*}(8 \cdot 0)$ & $37 \quad(5 \cdot 5)$ & $40 \quad(6 \cdot 6)$ \\
\hline $35 \quad(2 \cdot 7)$ & & $33 \quad(5 \cdot 2)$ & $35 \quad(6 \cdot 2)$ \\
\hline $34 \quad(6 \cdot 3)$ & & $32 *(4 \cdot 4)$ & $33^{*}(7 \cdot 0)$ \\
\hline $32^{*}(6 \cdot 3)$ & & $31^{*}(5 \cdot 2)$ & $\begin{array}{l}32(7 \cdot 5) \\
22^{*}(4 \cdot 8)\end{array}$ \\
\hline $26^{*}(7 \cdot 6)$ & $26^{*}(8 \cdot 2)$ & $29 \quad(6.5)$ & $21^{*}(6.4)$ \\
\hline $24^{*}(3 \cdot 3)$ & & $24 \quad(7 \cdot 6)$ & \\
\hline
\end{tabular}

* ${ }^{125}$ I-labelled surface proteins.

labelled spots were detected in these and other gels. An immunoblot of a similar gel with an anti-60 kDa monoclonal antibody detected the OMP2 (Allen \& Stephens, 1989), a cysteine- and methionine-rich protein, at the cathodic end, as had been noted for non-LGV serovars (Batteiger et al., 1985). Eleven unique HeLaspecific proteins and $22 \mathrm{McCoy}$-specific ones were detected in these and other gels of $C$. trachomatis serovar E (Table 1). It should be noted that no host-dependent change was detected in the molecular mass or the $\mathrm{pI}$ of the MOMP or of the $60 \mathrm{kDa}$ OMP2 protein and these two proteins served as highly reproducible internal markers to align the fluorographs. There were several proteins of identical molecular mass but differing in $\mathrm{pI}$ among the host-specified proteins of serovar E (Table 1). Identical data were obtained from replicate experiments.

Numerous unique host-specified ${ }^{35} \mathrm{~S}$-labelled proteins of an LGV serovar (L1) grown for multiple passages in HeLa and in McCoy cells were also detected on fluorographs of the 2-D gels and their properties have been summarized in Table 1. Twenty-one HeLa- and 19 McCoy-specific proteins of serovar Ll were detected. Some of the proteins migrated to the same molecular mass regions but had different pI. No change in either the molecular mass or the $\mathrm{pI}$ of the MOMP or OMP2 was seen in the EB of serovar L1 due to host passage, similar to the situation with serovar $\mathrm{E}$. The $45 \mathrm{kDa}$ protein of $\mathrm{L} 1 / \mathrm{McC}$ oy had a lower $\mathrm{pI}$ than the identical protein from $\mathrm{L} 1 / \mathrm{HeLa}$ (Table 1). The $32 \mathrm{kDa}$ protein detected in the EB of $\mathrm{L1} / \mathrm{McCoy}$ had a different $\mathrm{pI}$ relative to the identical protein in the $\mathrm{L} 1 / \mathrm{HeLa}$ (Table 1). The 2-D gel analysis of HeLa- or McCoy-grown serovar L1 has been done three times with identical results, ruling out the possibility of variations in the IEF gels contributing to the changes detected.

The host-specific proteins that were detected after 2-D electrophoresis of the purified EB of either serovar E or $\mathrm{L} 1$ after growth adaptation in $\mathrm{HeLa}$ or McCoy cell lines were apparent only after five to six serial passages in the respective host (data not shown). The appearance and disappearance of the unique chlamydial proteins characteristic of the host cell were reversible.

\section{Host-specified surface proteins of chlamydiae}

Serovars $\mathrm{L} 1$ and $\mathrm{E}$ were grown for $>20$ passages in $\mathrm{HeLa}$ and in McCoy cells. Purified EB were iodinated as described in Methods. After 2-D electrophoresis and autoradiography, 23 spots from the purified EB of $\mathrm{Ll} / \mathrm{HeLa}$, and 19 from $\mathrm{Ll} / \mathrm{McCoy}$ could be detected (Fig. $2 a$ ). Similar analysis of the ${ }^{125} \mathrm{I}$-labelled surface proteins of $C$. trachomatis serovar E revealed 15 spots from $\mathrm{E} / \mathrm{HeLa}$, and 19 from $\mathrm{E} / \mathrm{McCoy}$ (Fig. 2b). The unique host-specific proteins detected in the autoradiographs are marked with an asterisk in Table 1. Among these were the following: eight HeLa-specific and four McCoy-specific proteins in the EB of serovar L1; seven HeLa-specific and 11 McCoy-specific ${ }^{125}$ I-labelled proteins in serovar E. When the iodinated EB suspension was incubated with trypsin $(1 \mu \mathrm{g}$ per $10 \mu \mathrm{g}$ chlamydial protein, $2 \mathrm{~h}$ at $37^{\circ} \mathrm{C}$ ), none of the iodinated spots could be detected by 2-D analysis and autoradiography.

\section{Host-modulated membrane-binding proteins}

HeLa- and McCoy-adapted serovar E and L1 proteins were separated by 1-D electrophoresis, and transferred to Immobilon $\mathrm{P}$ membranes by the method of Towbin et al. (1979). Iodinated HeLa membrane was used to probe the membrane-binding chlamydial proteins as described in Methods. Protein bands additional to the 32 and $18 \mathrm{kDa}$ proteins (Hackstadt, 1986; Wenman \& Meuser, 1986) were detected on the Immobilon $\mathbf{P}$ membranes, pre- 

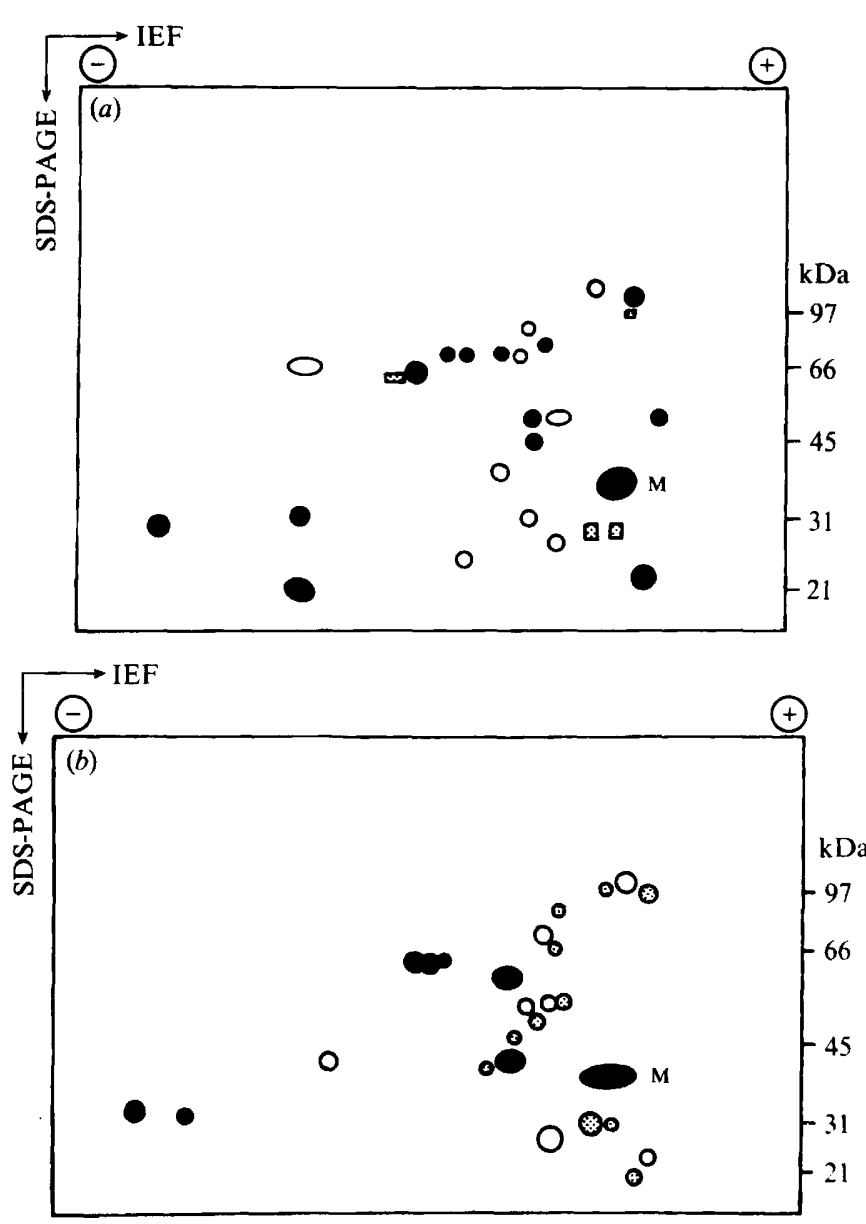

Fig. 2. Composites of paired autoradiographs of the surface-iodinated protein profiles obtained by 2-D electrophoresis of $C$. trachomatis serovars L1 $(a)$ and E (b) grown for multiple passages in HeLa and in McCoy cells. The purified EB were labelled extrinsically with ${ }^{125} \mathrm{I}$ as described in Methods, and subjected to 2-D electrophoresis and autoradiography. Proteins common to both HeLa- and McCoygrown chlamydiae; $O$, proteins unique to HeLa-grown chlamydiae; 惫, proteins unique to McCoy-grown chlamydiae. $M$ is the location of the MOMP of both samples. Positions of molecular mass markers are shown.

sumably due to a superior transfer of the chlamydial proteins from the gels to the Immobilon $\mathbf{P}$ membranes and by the buffer system utilized for the transfer (Towbin et al., 1979). Both types of HeLa membranes bound to essentially identical chlamydial proteins of the two serovars. The results are summarized in Table 2. HeLaas well as McCoy-specific proteins of molecular mass 70 , $58,40,32$ and $18 \mathrm{kDa}$ in serovars $\mathrm{Ll}$ as well as E consistently exhibited the ability to bind isolated iodinated host cell membrane. The $58 \mathrm{kDa}$ protein was as capable of binding the HeLa membrane preparations as were the 32 and $18 \mathrm{kDa}$ chlamydial proteins. It was ascertained to be the cysteine-rich OMP2 by immunoblotting with an anti-60 kDa monoclonal antibody. The
Table 2. Membrane-binding proteins of Chlamydia trachomatis serovars $\mathrm{E}$ and $\mathrm{Ll}$ : effect of adaptation in $\mathrm{HeLa}$ or McCoy cells

Membrane-containing material was prepared from monolayer cultures of HeLa cells (Wenman \& Meuser, 1986), and iodinated using Iodobeads. The chlamydial proteins were resolved by $1-\mathrm{D}$ electrophoresis, electroblotted to an Immobilon $P$ membrane and probed with iodinated HeLa membrane as described in Methods.

\begin{tabular}{ccccc}
\hline & \multicolumn{3}{c}{ Membrane-binding proteins (kDa) } \\
\cline { 2 - 3 } \cline { 5 - 6 } $\begin{array}{c}\text { Molecular mass } \\
\text { range (kDa) }\end{array}$ & HeLa & McCoy & HeLa & McCoy \\
\cline { 2 - 5 } $75-50$ & 70 & 70 & 70 & 70 \\
& 58 & 58 & 58 & 58 \\
$50-39$ & $45^{*}$ & $50^{*}$ & $51^{*}$ & \\
& $43^{*}$ & $44^{*}$ & $43^{*}$ & \\
$39-27$ & 40 & 40 & 40 & 40 \\
& & $39^{*}$ & & $37^{*}$ \\
$27-17$ & 32 & 32 & 32 & 32 \\
& 18 & 18 & 18 & 18 \\
\hline \hline
\end{tabular}

Table 3. Host-passage-dependent unique antigenic determinants of serovar $E$

Proteins of $C$. trachomatis serovar $\mathrm{E}$ that had been passaged $>10$ times in HeLa and in McCoy cells were separated by 1-D gel electrophoresis, electroblotted on to a nitrocellulose membrane, and incubated with appropriately diluted sera from a rabbit immunized with $C$. trachomatis serovar L2/McCoy, and from a patient who had acquired infection with $C$. trachomatis $\mathrm{L} 2$ through aerosol inhalation during sonication of infected HeLa cells.

\begin{tabular}{ccccc}
\hline \hline \multirow{2}{*}{ Rabbit antiserum } & & \multicolumn{2}{c}{ Human antiserum } \\
\cline { 5 - 5 } E/HeLa & E/McCoy & & E/HeLa & E/McCoy \\
\hline 67 & 67 & 67 & 67 \\
$62^{*}$ & - & $62^{*}$ & - \\
60 & 60 & 60 & 60 \\
58 & 58 & & 58 & 58 \\
- & - & & $56^{*}$ & - \\
- & - & & $54^{*}$ & $55^{*}$ \\
$54^{*}$ & 47 & 47 & - \\
47 & MOMP & MOMP & MOMP \\
MOMP & & & \\
\hline \hline
\end{tabular}

* Unique proteins.

unique HeLa-specific proteins had molecular masses of 45 and $43 \mathrm{kDa}$ in serovar $\mathrm{L} 1$ and of 51 and $43 \mathrm{kDa}$ in serovar E (Table 2). The McCoy-specific chlamydial proteins that bound iodinated membrane fragments of HeLa cells were the following: for serovar Ll, 50, 44 and $39 \mathrm{kDa}$; and for serovar $\mathrm{E}$, only one protein of $37 \mathrm{kDa}$. 


\section{Host-modulated chlamydial antigens}

The proteins of $\mathrm{E} / \mathrm{HeLa}$ and $\mathrm{E} / \mathrm{McC}$ oy were analysed by immunoblotting using a polyclonal serum from a rabbit immunized with $C$. trachomatis $\mathrm{L} 2 / \mathrm{McCoy}$, and a serum from a laboratory member who had accidentally acquired a chlamydial infection by the inhalation of aerosol during sonication of L2-infected $\mathrm{HeLa}$ cells. Both sera reacted very strongly with the $60 \mathrm{kDa}$ protein and the MOMP of E/HeLa and E/McCoy. Both sera recognized two unique $\mathrm{E} / \mathrm{HeLa}$ proteins of 62 and $54 \mathrm{kDa}$. The human serum recognized an additional unique $56 \mathrm{kDa}$ protein in the $\mathrm{EB}$ of $\mathrm{E} / \mathrm{HeLa}$, and another one in $\mathrm{E} / \mathrm{McC}$ oy of $55 \mathrm{kDa}$ (Table 3).

\section{Discussion}

This study was initiated to determine if the host-passagedependent altered adherence of $C$. trachomatis to mammalian cells (Bose \& Goswami, 1986) resulted from the acquisition of host-specified proteins that mediated this step. Data presented here indicate that numerous protein differences develop between the same serovar of chlamydiae after growth in different hosts. These unique host-specified chlamydial proteins include several that are surface-exposed (Figs 1 and 2, Table 1). Since these alterations become detectable only after more than four passages in the two hosts and in a reversible manner (data not shown), host protein contamination in the EB preparations is ruled out as the probable reason for these differences. Iodination of the purified EB resulted in labelling of only the surface proteins, since treatment of the iodinated EB suspension with trypsin removed all the labelled proteins. We were unable to detect iodinated $18 \mathrm{kDa}$ protein in serovars $\mathrm{L} 1$ and $\mathrm{E}$, regardless of their passage history (Fig. 2, Table 1). Also noteworthy are the host-passage-dependent changes in the $32 \mathrm{kDa}$ protein labelled with ${ }^{125} \mathrm{I}$ in serovars $\mathrm{E}$ and $\mathrm{Ll}$ grown in HeLa or in McCoy cells (Table 1).

At least two proteins have been isolated from several serovars of $C$. trachomatis that bind Triton X-100solubilized membrane-containing material from HeLa cells (Hackstadt, 1986). Similar HeLa-membrane-binding chlamydial proteins of 18 and $32 \mathrm{kDa}$ were also found in serovars $J$ and L2 (Wenman \& Meuser, 1986). In both studies the chlamydiae had been propagated in HeLa cells. Our membrane-blotting experiments detected several additional and host-specific chlamydial proteins capable of binding membrane preparations from HeLa cells (Table 2). When the electrophoretic transfers were done in the phosphate buffer system used by Hackstadt (1986) and Wenman \& Meuser (1986), only the 32 and $18 \mathrm{kDa}$ proteins exhibited membrane-binding activity (data not shown). Experiments are in progress to determine which, if any, of these multiple chlamydial proteins mediate the adherence step in the initiation of infection.

Immunoblotting experiments with serovar $\mathrm{E}$ grown in $\mathrm{HeLa}$ or in McCoy cells, using as probes serum from an immunized rabbit, and from an individual who was accidentally infected with $C$. trachomatis, have shown that the immune response includes common as well as host-specific antigens. Among the many chlamydial proteins that reacted with the two polyclonal sera, proteins of 62,56 , and $54 \mathrm{kDa}$ were present only in the $\mathrm{EB}$ of $\mathrm{E} / \mathrm{HeLa}$ (Table 3). Only a single unique E/McCoyspecific protein $(55 \mathrm{kDa})$ was detected using the human serum. It is noteworthy that the rabbit was immunized with L2/McCoy, while the patient had been infected with L2/HeLa.

Analyses of the whole EB lysates, the surface-exposed proteins, the membrane-binding proteins and the response to the polyclonal sera suggest that with the adaptation of chlamydial serovars to growth in the different hosts, numerous proteins undergo modulation of expression determined by the host cell. Some of these host-specified proteins are surface-exposed, and some appear to be unique antigenic determinants. Interestingly, the two major constituents of the outer membrane of this intracellular bacterium, the MOMP and the OMP2 proteins, remain conserved in both molecular mass and pI during the host adaptation, and indeed serve as internal markers for 2-D analyses. It seems rather tenuous to consider these numerous chlamydial proteins to be host-modulated 'stress proteins'. Nevertheless, it is possible that chlamydial growth in the different host cells that are routinely used in laboratories induces hostmodulated expression of proteins whose functions remain unknown.

We had speculated that this intracellular pathogen might acquire surface antigens that enable it to escape the host's immune surveillance system (Bose \& Goswami, 1986). The surface protein labelling and the immunoblotting data presented here reinforce this hypothesis, implying that host-specific proteins may be involved in the immune response mechanism. While additional evidence must be obtained to show that true antigenic variation occurs in the proteins involved in immunogenicity following chlamydial infection, it seems reasonable to us that this obligately parasitic bacterium mimics other bacterial and viral pathogens which manage to survive in a hostile milieu.

\footnotetext{
This work was supported by grants from the Edna McConnell Clark Foundation (02787), the NATO Scientific Affairs Division and the National Institutes of Health (AI 19575). We are grateful to Dr Theresa Joseph for her valuable contribution to this study. We thank Mrs Maria $\mathrm{J}$. Weingartner for her secretarial assistance in the preparation of the manuscript.
} 


\section{References}

Allan, I. \& Pearce, J. H. (1979a). Host modification of chlamydiae: differential infectivity for cell monolayers of chlamydiae grown in eggs and monolayers. Journal of General Microbiology 112, 53-59.

Allan, I. \& Pearce, J. H. (1979 b). Host modification of chlamydiae: presence of an egg antigen on the surface of chlamydiae grown in the chick embryo. Journal of General Microbiology 112, 61-66.

Allen, J. E. \& Stephens, R. S. (1989). Identification by sequence analysis of two-site posttranslational processing of the cysteine-rich outer membrane protein 2 of Chlamydia trachomatis serovar L2. Journal of Bacteriology 171, 285-291.

Ames, G. F. L. \& NiKaIDo, K. (1976). Two dimensional gel electrophoresis of membrane proteins. Biochemistry 15, 616 -623.

BatTeiger, B. E., Newhall, W. J. V. \& JONES, R. B. (1985) Differences in the outer membrane proteins of the lymphogranuloma venereum and trachoma biovars of Chlamydia trachomatis. Infection and Immunity 50, 488-494.

Bose, S. K. \& Goswami, P. C. (1986). Host modification of the adherence properties of Chlamydia trachomatis. Journal of General Microbiology 132, 1631-1639.

Bose, S. K., Smith, G. B. \& Paul, R. G. (1983). Influence of lectins, hexoses, and neuraminidase on the association of purified elementary bodies of Chlamydia trachomatis UW-31 with HeLa cells. Infection and Immunity 40, 1060-1067.

GoRDON, F. B., Nichols, R. L. \& QUAN, A. L. (1971). Immunotyping of Chlamydia trachomatis with fluorescent antibody: retention of immunospecificity in cell culture passage, and typing with infected cell monolayers. In Trachoma and Related Disorders, pp. 358-362. Edited by R. L. Nichols. Amsterdam: Excerpta Medica.

Goswami, P. C., Vretou, E. \& Bose, S. K. (1988). Altered polypeptides acquired during the growth of Chlamydia trachomatis in human or murine cells. Annual Meeting of the American Society of Biochemistry and Molecular Biology. Journal of Cell Biology 107, 145a.

HACKSTADT, T. (1986). Identification and properties of chlamydial polypeptides that bind eucaryotic cell surface components. Journal of Bacteriology 165, 13-20.
Kordova, N., Poffenroth, L. \& Wilt, J. C. (1972a). Lysosomes and the 'toxicity' of Rickettsiales. II. Non-cytocidal interaction of egggrown $C$. psittaci $6 \mathrm{BC}$ and in vitro macrophages. Canadian Journal of Microbiology 18, 869-873.

Kordova, N., POFFENRoth, L. \& WILT, J. C. (1972b). Lysosomes and the 'toxicity' of Rickettsiales. III. Response of L cells infected with egg-attenuated $C$. psittaci 6BC strain. Canadian Journal of Microbiology 18, 1343-1348.

Kordova, N., Martin, C., Wilt, J. C. \& Neuman, M. (1977). Sucrose density differences of Chlamydia psittaci $6 \mathrm{BC}$ in relation to its host. Canadian Journal of Microbiology 23, 649-652.

LAEMMLI, U. K. (1970). Cleavage of structural proteins during the assembly of the head of bacteriophage T4. Nature, London 227, 680685.

MarRiott, S. J., Griffith, G. R. \& Consigli, R. A. (1987). Octyl- $\beta$-Dglucopyranoside extracts polyomavirus receptor moieties from the surfaces of mouse kidney cells. Journal of Virology 61, 375-382.

Neuman, M. R., Kordova, N. \& WiLt, J. C. (1980). Host influence on the density of chlamydiae in Renografin gradients. Zentralblatt für Bakteriologie, Mikrobiologie und Hygiene (Abteilung I, Originale A) 247, 526-529.

O'Farrell, P. H. (1975). High-resolution two-dimensional electrophoresis of proteins. Journal of Biological Chemistry 250, 4007-4021.

Towbin, H., Staehelin, T. \& Gordon, J. (1979). Electrophoretic transfer of proteins from polyacrylamide gels to nitrocellulose sheets: procedure and some applications. Proceedings of the National Academy of Sciences of the United States of America 76, 4350-4354.

Vretou, E., Goswami, P. C. \& Bose, S. K. (1989a). Host-modulated proteins of Chlamydia trachomatis and their role in adherence. Proceedings of the 8th Meeting of the International Society for Sexually Transmitted Diseases Research, abstract no. 23. Copenhagen: ISSTDR.

Vretou, E., Goswami, P. C. \& Bose, S. K. (1989b). Adherence of multiple serovars of Chlamydia trachomatis to a common receptor on HeLa and McCoy cells is mediated by thermolabile protein(s). Journal of General Microbiology 135, 3229-3237.

WenMan, W. M. \& Meuser, R. V. (1986). Chlamydia trachomatis elementary bodies possess proteins which bind to eucaryotic cell membranes. Journal of Bacteriology 165, 602-607. 